\title{
Design of Agro-Education Tourism Accounting Information System
}

\author{
Anak Agung Gde Satia Utama* \\ Department of Accounting, Faculty of Economics and Business, Airlangga University Indonesia
}

\author{
*Corresponding Author \\ Anak Agung Gde Satia Utama
}

\section{Article History}

Received: 13.12.2020

Accepted: 21.12.2020

Published: 24.12.2020

\begin{abstract}
Land Extensive agriculture can be the primary source of income for rural communities through tourism vehicles. Good management must be accompanied by the integration of village resources in it. Tamansari Village received the title as the best tourist village included in the category of utilizing business networks. One of the tourist objects that have been in the village of Tamansari for a long time is the Etawa goat farming education tour. Agro-tourism is needed nowadays to develop a regional potential in the form of natural resources in agriculture. This research's main objective is to design a QR-code-based sales system in the etawa goat farm tour to facilitate the payment and allocation of income for each tenant and tourism managers. This study uses a qualitative exploratory methodology. The data used in this study are quantitative and qualitative. The data were then analyzed using triangulation techniques. This study describes how the system is formed through flowchart design, data flow diagrams, and entity-relationship diagrams. Cost and benefit analysis is needed to determine whether the system being built can be implemented. Sales accounting information system with QR-code designed in Etawa goat farm tourism is expected to facilitate the payment and allocation of income for each tenant and tourism managers.
\end{abstract}

Keywords: Design of Agro-Education Tourism Land Extensive Tamansari.

\section{INTRODUCTION}

Sizeable agricultural land can be the primary source of income for rural communities through tourism vehicles. The beauty of nature tourism in the village wrapped in local wisdom deserves to be considered agribusiness tourism. If the tour is well managed and systemized, it can attract domestic and foreign tourists.

Good management must be accompanied by the integration of village resources in it. Tourist facilities, entry access, information systems, and human resources are the main focus of agribusiness tourism. This article will discuss how agro-tourism information systems can help increase the income of the Tamansari village community.

Tamansari Village, which is included in Licin Subdistrict, Banyuwangi won an award at the "Tourism Village Award" from the Ministry of Villages, Disadvantaged Villages and Transmigration referred to as the Ministry of PDT. The village on the slopes of Mount Ijen is the best tourism village in utilizing business networks. Tamansari Village received the title as the best tourist village included in the category of utilizing business networks. According to the Regent of Banyuwangi, Mr. Anas explained that Tamansari village deserves an award because it successfully pioneered the development of its tourism potential commercially. This village-owned enterprise (BUMDes) has also developed many businesses starting from its potential. Such as honey business, tourist vehicles, guide services, and many smallmedium scale businesses. Until now, Tamansari Village has had a strong foundation for integrated agro-tourism with other cultural tourism, creating a new tourism atmosphere in Banyuwangi.

One of the tourist objects that have been in the village of Tamansari for a long time is the Etawa goat farming education tour. This tour is an old tourist attraction that is still maintained by the community and the village government of Tamansari because the education of Etawa goat is only a side income from the production of Etawa goat milk. The lack of concern of the manager for the development of the educational tourism potential of Etawa goat on the proper

Copyright (C) 2020 The Author(s): This is an open-access article distributed under the terms of the Creative Commons Attribution 4.0 International License (CC BY-NC 4.0) which permits unrestricted use, distribution, and reproduction in any medium for non-commercial use provided the original author and source are credited. 
specifications and publication methods to attract consumer interest is one of the obstacles to the development of this tourist attraction.

Agro-tourism is needed nowadays to develop a regional potential in the form of natural resources in agriculture. This potential must be considered in various aspects. This aspect is the geographical location of the area, the natural environment, the types of products produced, or agricultural commodities produced, and the facilities and infrastructure available in the area [1]. Based on this, tourism activities must be a particular focus and production activities to develop natural potential and livestock according to tourism needs.

The educational tour of the Etawa goat farm school is a proposed agro-tourism development system. Previous research conducted by Zang, Mu, et al. [2], Surekha et al. [3], and Sikumbang [4] still focuses on the use of QR codes. In this study, researchers also combined RFID to determine which tourist objects visitors are most interested in.

Based on the above background, the problem's formulation can be raised: How do SIA sales with QR-codes in the etawa goat farm tour facilitate the payment and allocation of income for each tenant and tourism managers.

\section{LiTERATURE REVIEW}

E-commerce or electronic commerce is part of an electronic business that carries out purchases and sales of goods and services through the internet. These transactions include advertising, marketing, customer support, security, delivery, and payment [5].

According to Radovilsky [6], E-commerce is becoming a significant element in an increasingly modern global economic environment. E-commerce can be defined as using computer networks, especially using the internet, which users can use to sell or buy products, goods, and services and share information and communication media. E-commerce can increase efficiency, and the costs incurred by the company will be lower.

The definition of E-commerce has 3 (three) aspects as follows [6]:

1. Technology Aspects. E-commerce is the application of techniques used to increase business transactions that utilize internet-based websites.

2. Business Aspects. E-commerce is used to provide the ability to buy or sell a product, both in the form of goods and services and supporting information in the form of an internet-based website.

3. Value Aspects. E-commerce is a business tool, both from the customer and consumer side, to create value in internet-based transactions; the goal is to increase efficiency and cut costs when a business wants to improve product quality.

E-Pay, or often referred to as e-payment or electronic payment, is a payment mechanism made by customers to purchase goods and services using the internet [7]. According to Tan [8], the opinion supports this: e-payment is a money transfer made electronically or digitally, which involves two parties considered as compensation or payment for a good or service.

There are four parties involved in the implementation of e-payment; these parties are [7]:

a) The issuer, this party, is a bank or other non-bank institution tasked with issuing e-payments that will later be used for sales transactions and purchasing goods or services online.

b) Customer (buyer), this party is a buyer who makes payments for purchases of goods or services made online.

c) Merchant (seller), this party is a seller who makes payments for sales of goods or services made online.

d) The regulator is the government party in charge of making all regulations related to the e-payment process.

Turban et al. [7] also explained that there are five types of e-payments, namely:

a) Payment Card, in this type of e-payment, payment is made via credit card or debit card.

b) E-Wallet, in this type of e-payment, users must have an account that contains data on the amount of money they have that can be used for sales and purchase transactions of goods and services online.

c) In this type of e-payment payment, Smart Card is made through a special card that has been embedded with a unique microchip, electronic memory, and a battery in it. The smart card is also equipped with information from users who are entitled to use the card.

d) E-Cash, this type of e-payment is previously in the form of paper and coins but looked like a digital version. Payments for purchases of goods and services at low prices are safer.

e) E-Check, this type of e-payment is a check that looks digital and can be cashed directly at the bank. 
According to Daulay [9], QR (Quick Response) Code is one form of evaluation of barcodes that are usually listed on a product. This QR code has a square array shape and is black, at first glance like a barcode but has a more straightforward and more concise appearance. QR codes contain various kinds of information, including URL addresses, telephone numbers, and specific text information. QR codes are usually listed on a product that contains additional information attached to a product. This QR code can only be read via a smartphone with a camera and a $\mathrm{QR}$ code reader application.

Symbol Technologies has implemented PDF417 (two-dimensional barcode) since 1991. This technology is widely used for various purposes, namely, national defense, public security, public transportation, health, manufacturing, business, finance, customs, and government [10]. Japan and South Korea later developed this technology. This technology is then referred to as the QR Code. This WR code was designed by a company in Japan called Denso Wave in September 1994 [11]. What distinguishes this technology from the previous technology is if the barcode is a twodimensional matrix data applied to cellphones. In contrast, the QR Code data matrix can be applied to mobile communication.

The definition of Radio Frequency Identification (RFID), according to Thronton [12] in Fadhilatul [13], is equipment and technology whose performance uses radio signals. The radio signal is used to provide identified data. RFID is usually in the form of a small label or tag used to identify a data object that is received via radio, and the object is then translated back into a number or other form. The RFID components proposed by Narayana et al. [14] in Fadhilatul [13] are RFID tags. Self-check-in / out stations, staff check-out stations, self-return book drops with automatic check-in features, a tag station equipped with a tag reader. Meanwhile, according to Boss [15] in Fadhilatul [13], there are two primary components in RFID these components are (1) an RFID tag that has been programmed electronically will be unique information and (2) a reader or sensor to interrogate tags. The use of servers that have been configured using RFID will be a way of communication between various components.

Marketing Information System (MIS) is a system consisting of people, equipment, and procedures to collect, sort, analyze, evaluate, and distribute information needed, timely and accurately to marketing decision-makers. This relies on internal company records, intelligence marketing activities, and marketing research. In 1966 Professor Pillips Kotler from Northwestern University used the term marketing nerve center to describe a new marketing unit that collects and processes information and marketing unit.

The MIS model is explained that it consists of three parts, namely Output, Database, and Input.

1. Output (Product, Place, Promotion, Price, Integrated mix)

2. Database

3. Input (Accounting Information System, Marketing Research, Marketing Intelligence). In the accounting information system (AIS), sales order data is the input. The purpose of the AIS is to provide data. Then the data is used for periodic reports, special reports, and the knowledge business model.

A relational database is a database that implements data stored in a series of two-dimensional tables that are "linked" to each other via foreign keys. The physical data model is called a schema. DDL and DML for relational databases are called SQL (Structured Query Language).

Triggers are programs embedded in the database that is automatically updated. Stored procedures are programs that are embedded in a database that can be called or returned from an application program.

According to Laudon [5], a database is a collection of several mutually organized data that is used to provide additional information for various applications simultaneously, either storing or managing data, to be seen in one efficient location. The existence of a database will help centralize data and minimize redundant or duplicate data. This is because database technology does not store data files separately for each application used by the company. However, stored in one place and can be accessed from various applications.

The database commonly used to analyze a system consists of three parts, namely [16]:

1. Field.

The field is the smallest part of the database. The field is an application of a data attribute. Four types of fields can be stored in the database as follows:

a. Primary keys are all fields used to identify alternatives that exist in one record in a database. A database consists of only one primary key.

b. The secondary key is all fields used to identify alternatives that exist in records in a database. In a database, there can be more than one secondary key. 
c. Foreign keys are all fields whose locations are located in records in other files in a database.

2. Descriptive fields are all other fields stored in business data.

3. Record

What is meant as a record is collecting various fields that have been integrated and arranged according to a predetermined format.

4. Files and Tables

The file is a collection of various records arranged following a predetermined format. Meanwhile, the table is the equivalent of a relational database contained in the file. There are six types of conventional files and tables, as follows:

a. A master file or table is a file or table containing records that are fixed.

b. A transactional file or table is a file or table containing records that describe the business processes that occur.

c. Documents file and table is a file or table containing a copy of historical data stored, used to facilitate recall and review without paying additional costs to produce the required documents.

d. Archival files and tables are files or tables that contain records from the master file and transactions that have previously been deleted from online storage.

e. Table look-up is a file or table consisting of relatively fixed data used in various applications to maintain consistency and improve performance.

f. An audit file is a file or table containing updated records explicitly used for other file types, especially master files, and transactions.

Cost and benefit analysis is a systematic and investigative process [17] to calculate and compare the costs and benefits of developing a project or a decision. This analysis is useful whether the project or decision exceeds its budget.

In principle, this cost and benefit analysis has two objectives, namely:

a) They determine whether the decision or project is an investment by conducting a feasibility study [14, 18].

b) Provide a basis for comparing the total costs incurred with the benefits obtained from the project or decision.

c) For each cost and benefit analysis, templates, or instructions have been prepared. The analysis carried out is in financial, economic, and risk assessment analyses [20], making it easier for researchers to calculate and analyze any costs that arise and the estimated benefits obtained.

\section{Research Methodology}

This research uses a qualitative exploratory methodology. This study aims to collect preliminary information to determine problems and formulate hypotheses [16]. Following the research problem, it is analyzing the tourism potential in the Tamansari village regarding sustainable etawa goat farming educational agro-tourism. The development of agrotourism uses the RFID system to capture or record input data regarding the visit's length, the most popular tourist attractions. In contrast, the use of the e-payment system uses a QR Code, which is to make it easier to record transactions automatically and integrated and automatic profit sharing that will go to management, local government in this case regarding taxes, and tourism tenants. Therefore, researchers need data that is documentation, observation, and interviews.

The research design was a research blueprint, concerning at least four problems: what questions to ask, what kind of data is said to be relevant, what data should be collected, and how to analyze the results [12]. Five components of the research design are essential [12], namely:

1. Research questions The research

Questions will later serve as a direction in shaping the writer's perception in continuing the writing process found directly in the field. This question was developed through the initial problem or issue raised by the author, namely "E-Pay Payment System Based on QR Code Agro-tourism for Sustainable Education of Etawa Goats in Tamansari Tourism Village," which can provide direct educational tours about Etawa goats to elementary school children.

Putra and Dwilestari 2012, in Putra [12] explain that qualitative research questions must meet several requirements, namely:

e) Open, not limited in the form of relationships between variables that are closed as in quantitative research

f) Context, there is a social setting in which research is carried out

g) Participants, namely the person or community being studied

h) The focus, subject, or main topic of research 
As for the smooth running of the research, the writer sets out an outline of the interview questions that include:

a. Tenant

- What are the duties and functions of the Tenant?

- How is the distribution of profits to tenants so far?

b. Tourism manager

- What is the system for recording sales income transactions?

- What is the trend of tourists' desire for tourist attractions?

- Is it possible to establish a diversification of etawa goat farm tourism?

- How is diversification desired to increase the number of tourists?

- How is the profit-sharing to the tour manager?

- How are the tax payments made?

c. Elementary School

- Is there a need for direct learning about etawa goats?

- What kind of educational tourism program does the school want?

d. Bank

- Is it possible to make payments using a QR code?

- What is the desired cooperation agreement with tenants and tour managers?

2. Unit of analysis

The analysis unit defined in the research design will later determine the sample size and the strategy in the study. The unit of analysis is a focus on the imposition of the research object. According to Bungin [18], the distribution of meaning in the substance of qualitative research has a level that will directly impact the resulting target object according to what the writer takes and the execution of writing in the end. The research object in question is the educational agro-tourism of the Etawa goat in Tamansari Village.

\section{Research Scope}

This study intends to recommend a new system related to a QR Code-based e-pay payment system design for sustainable educational agro-tourism provided. The constraints that form the research object:

1. determine the research area in Tamansari Village

2. research can be carried out in related agencies as long as the relevant data is still relevant and valid

3. Village tours that will use payment via e-pay are tours that can be identified, namely etawa goat educational agro-tourism.

\section{The types of data used by the author in this study are}

a. Quantitative Data Quantitative

Data is data in the form of numbers which will later become sources and reference evidence that supports qualitative data such as school data that will be targeted for educational agro-tourism promotion, student NISN data that will be used for making education training certificates for etawa goat farm education, data on the number of students who will be participating, data on the potential attractions of Etawa goat farm, data on the number of visitors to Etawa goat tourism, data on tax revenue from tourism.

\section{b. Qualitative data}

1) Primary data Primary

data is data obtained directly from the institution under study. The primary data will be interviews and observations related to the etawa goat livestock process, which is now being carried out until the etawa goat educational tourism diversification development model can be applied.

2) Secondary

Data Secondary data comes from literature and literature studies such as documentation from print and online media related to research. This is to support the course of research and as a theoretical basis in writing and as a starting material before conducting research. These data include:

a) The theory used in the study

b) The current tourist visit procedure

c) Initial understanding of the current system of site visits

d) Understanding of tourism tax collection

e) The real application of systems to be developed in other countries

f) New system design procedures for 
Data collection with documentation means that researchers conduct studies, study, review documents, and archival records received or obtained from sources. Making notes (taking notes) to emphasize (highlight) may be needed when a researcher finds something necessary in the documentation / archival notes he is studying.

The validity (validity) of data from various sources and the reliability (reliability) of data collection methods can be tested through triangulation [23].

Analysis Technique

a. Data triangulation is a triangulation of the sources and types of data collected by researchers. Triangulation of this data is done by comparing and checking the degree of confidence of information by, among others:

- Comparing the data from one observation to another.

- We are comparing the results of interviews with someone else.

- You are comparing one document with another document.

- They were comparing what the informant said in public with what was said in private.

b. Triangulation method. The triangulation method is done by comparing various kinds of data and data collection methods. Method triangulation is done by comparing various kinds of data and by collecting data. This type of triangulation is used to "test" the reliability (reliability) of data collection methods, by among others:

- Checking whether the data/information obtained from interviews is consistent with observations and vice versa

- Checking whether interviews and observations are consistent with documentation

- Comparing quantitative and qualitative data, either sequentially and or simultaneously.

\section{DISCUSSION}

Tamansari village has various tourism potentials ranging from natural landscape landscapes, plantation agrotourism to animal husbandry. One of the most unique and worthy to be developed is the Etawa goat tour in Tamansari Village. Until now, Etawa goat farm tourism is still relatively common. Visitors only come to the farm and buy Etawa goat milk; there is no further diversification in the etawa goat farm tourism.

The etawa goat farm's empowerment is only devoted to the production of etawa goat milk and only for sale. Further diversification for livestock development is still absent. The prospect of developing educational farms is in great demand in Indonesia. This is based on the results of marketing research conducted. Many schools and parents want direct education in the field because they are considered different from school. Schools are only able to offer library research, not on a practical basis. Another study shows that mental and motor development at the age of children can be honed by playing with animals and doing other practical work directly.

In addition to the diversification of the etawa goat farm, paying taxes is also a problem because the tax itself is still paid manually. Tax manipulation can occur by the management of the etawa goat farm. including:

Several opportunities can be developed in the effort to diversify Etawa goat farm tourism in Tamansari Village,

a. Feeding attractions for Etawa goats. The feeding attraction for the Etawa goat is only limited to 5 people because it is feared that if too many visitors feed it, it will make the goat stress because of the crowd.

b. The attraction of etawa goat milking. The attraction of Etawa goat milking is the same system as the attraction of feeding the goat, which is carried out alternately, limited to 5 visitors, and must be supervised by the teacher.

c. The attraction of making Hand Crafting from clay mixed with selected Etawa goat manure to make land directly planted with plants.

d. They are playing with Etawa goats. In this case, the Etawa goat will be invited to play by stroking the Etawa goat's hair. Etawa goats that are included in this attraction are toddlers, not babies.

e. 5. farm school that will be held during school children's holidays. Attractions only occur during the school holidays. The content of this attraction is to teach children to become real breeders, starting from finding food for Etawa goats to milking Etawa goats. 
Here are the details of the Happy Kids package costs.

Details of the costs and facilities for the Happy Kids Package Tour

\begin{tabular}{|l|l|l|}
\hline Item & Details & Total \\
\hline Lunch & 10,000 & Rp. 10,000 \\
\hline courage charter & 10,000 & Rp. 10,000 \\
\hline Tour guide & 50,000 & Rp. 50,000 \\
\hline Business development & 10,000 & Rp. 10,000 \\
\hline \multicolumn{2}{|c|}{ Total Rp. 80,000} \\
\hline
\end{tabular}

Source: sentulfresh educational tour (sentulfresh.com) 2017, processed data

Meanwhile, for the superkids package, it can be seen in the following table:

\begin{tabular}{|l|l|l|}
\hline Item & Details & Total \\
\hline Lodging & 250,000 & Rp. 250,000 \\
\hline Eat & $10,000 \times 14$ days & Rp. 140,000 \\
\hline courage charter & 10,000 & Rp. 10,000 \\
\hline Tour guide & 100,000 & Rp. 100,000 \\
\hline Business development & 60,000 & Rp. 60,000 \\
\hline Etawa milk & $40,000 \quad$ Rp. 40,000 \\
\hline \multicolumn{2}{|c|}{ Total } & Rp. 600.000 \\
\hline
\end{tabular}

Source: sentulfresh education tour (sentulfresh.com) 2017, processed data

This e-pay system using QR Code involves five parties. These parties are the Tourism Manager, Customers, Tenants, Banyuwangi Regency Government (Tax), and Banks. The tourism manager is the main admin who knows the number of tourism objects, tenants, customers, and banks invited to cooperate. Customers here are invited to work together, which are the parties that use the QR Code in making payments when visiting the tourism objects provided. Tenants have been invited to work together by the manager to organize tourism objects for the public. The district government in this area is the party that collects tourism taxes from administrative management. Meanwhile, the bank only acts as an intermediary for payments that enter from the QR code and deposit taxes to the district government's office in charge of collecting taxes.

There are five processes involved in registering tourism objects, processing transactions, and paying taxes. The five processes are registering tourism objects, registering tourist attraction owners, recording transactions that occur via QR Code, adjusting management records with bank records, and tax adjustments.

The cost and benefit analysis can be performed if the components of the costs and benefits are known. This analysis will determine whether an information system project is feasible or not. The cost component will enter into the cash outflow (cash outflow). The benefit component will enter the cash inflow (cash inflow). Various methods can be used in carrying out a cost and benefit analysis. Among them is the payback period, net present value, return on investment, and internal return rate. What researchers use is the return on investment?

The following is an estimate of the cost and benefit components according to Jogiyanto in Prabantoro [24]. The formula used to calculate Return on Investment is as follows:

\section{ROI = (Total Benefit-Total Cost $) /$ Total Cost}

$\mathrm{ROI}=(\operatorname{IDR} 1,275,000,000-\mathrm{IDR} 849,000,000) / \mathrm{IDR} 849,000,000 \times 100 \%=0.50$

A project is said to be feasible if a value greater than 0 . So, the project above deserves to be accepted and carried out.

\section{CONCLUSiON}

Sales accounting information system with QR-code in etawa goat farm tourism can simplify the payment and allocation of income for each tenant and tourism manager. Several opportunities that can be developed to diversify Etawa goat farm tourism in Tamansari Village include 1. Feeding attractions for Etawa goats. 2. The attraction of etawa goat milking. 3. The attraction of making Hand Crafting from clay mixed with Etawa goat manure has been selected to make land directly planted with plants. 4. Playing with Etawa goats. 5. A farm school that will be held during school children's 
holidays. This research still focuses on tourist attractions from Etawa goats. It is hoped that in further research, QR Codebased agro-tourism with a combination of RFID will be made for other types of diversification of agricultural tourism vehicles found in Tamansari Village, Banyuwangi.

\section{REFERENCES}

1. Sumarwoto, J. (1990). Pengembangan Agrowisata: Potensi dan Prospek.

2. Zhang, M., Yao, D., \& Zhou, Q. (2012). The application and design of QR code in scenic spot's eTicketing system-a case study of Shenzhen Happy Valley. International Journal of Science and Technology, 2(12), 817-822.

3. Surekha, A., Anand, P. R., \& Indu, I. (2015). E-payment transactions using encrypted QR codes. International Journal of Applied Engineering Research, 10(77), 461.

4. Sikumbang, A. (2017). E-Tiket Bus Trans Batam Dengan Menggunakan QR-Code System Berbasis Android. Jurnal Teknik Ibnu Sina, 2(1): 2541-2647.

5. Laudon, K.C., Dan, L., Jane, P. (2016). Management Information System Managing the Digital Firm. 14th Edition, Pearson Education Limited, England.

6. Radovilsky, Z. (2015). Designing and implementing an e-commerce system. Cognella Academic Publishing.

7. King, D., Chung, H. M., Lee, J. K., \& Turban, E. (1999). Electronic commerce: A managerial perspective. Prentice Hall PTR.

8. Tan, M. (2004). E-payment: The Digital Exchange. Singapore: Singapore University Press.

9. Daulay, S. S. (2017). Hubungan antara QR Code dan Dunia Industri dan Perdagangan (Online). Tersedia pada http://www.kemenperin.go.id/download/6759/Hubungan-antara-QR-Code-dan-Dunia-Industri-dan-Perdagangan. Diakses pada 1 Oktober 2017 pukul 14.16.

10. Wang, Y.U. (2001). Research on image decoding based on two dimensional bar code. Beijing: Beijing Industrial University.

11. Qi, J. (2004). 2D barcode generation and recognition. Harbin: Harbin Engineering University.

12. Yin, R.K. (2006). Studi Kasus Desain dan Metode. (D. Mudzakir Penerj). Jakarta: PT. Raja Grafindo Persada.

13. Fadhilatul, H. (2014). Penerapan RFID di Perpustakaan. Jurnal Ilmu Perpustakaan \& Kearsipan Khizanah AlHikmah, 2(1): 71-79.

14. Allen, D. (2007). Cost/Benefit Analysis for Implementing ECM, BPM Systems. Information Management Journal 34-41.

15. Boss, P. (2007). Ambiguous loss theory: Challenges for scholars and practitioners. Family relations, 56(2), 105-110.

16. Whitten, D. (2007). Systems Analysis and Design Methods, 7th edition. Mc Graw Hill, Boston.

17. Berghout, E., Nijland, M., \& Powell, P. (2011). Management of lifecycle costs and benefits: Lessons from information systems practice. Computers in Industry, 62(7), 755-764.

18. Bungin, M. B. (2008). Penelitian Kualitatif. Jakarta: Kencana Prenada Media. Group.

19. Ali, A. (2012). A Framework for Using Cost-Benefit Analysis in Making the Case for Software Upgrade. Issues in Informing Science \& Information Technology, 9.

20. European Commission Guidance. (2014). Guidance to Cost-Benefit Analysis of Investment Projects. Europian Union, Italy.

21. Kotler, P., Kartajaya, H., \& Setiawan, I. (2016). Marketing 4.0: Moving from traditional to digital. John Wiley \& Sons.

22. Putra, N. (2012). Metodologi Penelitian Kualitatif Pendidikan. Jakarta: PT. Raja Grafindo Persada.

23. Basuki, B. (2016). Metode Penelitian Akuntansi dan Manajemen Berbasis Studi Kasus. Surabaya: Airlangga University Press

24. Prabantoro, G. (2002). Mengukur Kelayakan Ekonomis Proyek Sistem Informasi Manajemen Menggunakan Metode 'Cost \& Benefits Analysis' Dan Aplikasinya Dengan MS EXCEL 2000. 